\title{
BIOEDUSCIENCE
}

ISSN: 2614-1558

\section{The Potential of Noni (Moringa citrifolia) in Lowering Blood Glucose Levels in Diabetes Mellitus Patients}

\author{
Putri Dafriani ${ }^{*}$, Mutiara Karamika ${ }^{1}$, Siska Sakti Anggraini1 ${ }^{1}$, Roza Marlinda ${ }^{1}$ \\ ${ }^{1}$ Sekolah Tinggi Kesehatan Syedza Saintika, Jl. Prof. Dr. Hamka No. 228, Padang, Indonesia, 25132 \\ *Corespondent mail: putridafrianiabd@gmail.com
}

\section{ARTICLE INFO}

Received: 16 Apr 2020

Accepted: 02 Des 2020

Published: 31 Des 2020

\section{Keywords:}

Blood Glucose

Diabetes Mellitus

Morinda citrifolia

Noni Juice

\section{Article history:}

\section{A B S T R A C T}

Background: Diabetes Mellitus is a chronic metabolic disorder caused by insulin resistance. Hyperglycemia is one of the diabetic symptoms. Noni Juice is herbal medicine. It can decrease blood glucose level. This study aims to determine the effect of noni juice on blood sugar levels on diabetic patients. Methods: This study used 16 respondents. They divided two groups, a control group and a treatment group. Each group consists of 8 respondents. The intervention group received $150 \mathrm{ml}$ of noni juice which was given once a day for ten days. Glucose testing was carried out by the glucocheck method. The blood was taken from the respondent's fingertips capillary. The results of blood glucose levels between the control group and the intervention group were analyzed using independent t-test. Results: The average blood glucose level in the intervention group was $199.88 \mathrm{mg} / \mathrm{dl}$, while the control group was $326.25 \mathrm{mg} / \mathrm{dl}$. The test results of the mean blood glucose levels between the control group and the intervention group had a significant difference with a value of $\mathrm{p}=0.003(\mathrm{p} \leq 0.05$ ). This means that there was a significant effect between blood glucose levels in the control group and the intervention group. Conclusion: Noni can reduce blood glucose levels because it contains flavonoid. It has a hypoglycemic effect. Health workers can suggest consuming noni juice to decrease blood glucose in diabetic patients.

\section{Potensi Buah Mengkudu (Moringa citrifolia) dalam Menurunkan Kadar Glukosa Darah} Pasien Diabetes Mellitus

\section{A B S T R A K}

\section{Kata kunci:}

Diabetes Melitus

Kadar glukosa darah

Mengkudu

Morinda citrifolia
Background: Diabetes Mellitus merupakan gangguan metabolisme kronis yang disebabkan oleh resistensi insulin. Hiperglikemia merupakan salah satu gejala diabetes. Jus Mengkudu adalah salah satu tanaman obat yang dapat menurunkan kadar glukosa darah. Penelitian ini bertujuan untuk mengetahui jus buah mengkudu terhadap kadar gula darah pada penderita diabetes. Metode: Penelitian ini menggunakan 16 responden. Mereka dibagi menjadi dua kelompok, kelompok kontrol dan kelompok perlakuan. Setiap kelompok terdiri dari 8 responden. Kelompok intervensi mendapat $150 \mathrm{ml}$ jus mengkudu yang diberikan sekali sehari selama 10 hari. Pengujian glukosa dilakukan dengan metode glukocheck. Darah diambil dari kapiler ujung jari responden. Hasil pemeriksaan kadar glukosa darah antara kelompok kontrol dan kelompok intervensi dianalisis menggunakan uji-t independen. Hasil: Rata-rata kadar glukosa darah kelompok intervensi 199,88 mg / dl, sedangkan kelompok kontrol 326,25 mg / dl. Hasil pengujian rerata kadar glukosa darah antara kelompok kontrol dan kelompok intervensi terdapat perbedaan yang bermakna dengan nilai $p=0,003(p \leq 0,05)$. Artinya ada pengaruh yang signifikan antara kadar glukosa darah kelompok kontrol dan kelompok intervensi. Kesimpulan: Mengkudu dapat menurunkan kadar glukosa darah karena mengandung flavonoid yang memiliki efek hipoglikemik. Tenaga kesehatan dapat menyarankan agar mengkonsumsi jus mengkudu untuk menurunkan glukosa darah pada penderita diabetes. 


\section{Introduction}

Diabetes Mellitus (DM) is one of the chronic diseases that are widely found in the community. According to the IDF's 2015 7th edition of the Atlas Diabetes data, the number of diabetics is expected to rise from 415 million in 2015 to 642 million by 2040 (Forouhi \& Wareham, 2014). Nearly half of these are in Asia, especially China, Pakistan and Indonesia. The prevalence of DM in Indonesia increased from $6.9 \%$ in 2013 to $8.5 \%$ in 2018. In Kerinci region, based on the data from the Kerinci District Health Office in 2017, the number of people living with diabetes mellitus as many as 578 cases and this number increased to 614 cases in 2018 and 2019 from January to March, become 372 cases (Dinas Kesehatan Kabupaten Kerinci, 2019).

One of the clinical symptoms of DM is hyperglycemia (Babu et al., 2013), which has an impact on long-term complications (Aouacheri et al., 2015) and can cause angiopathy, resulting in disorders in many organs such as the heart, kidneys, nerves, retina, and others (Leon, 2015). This leads to rising morbidity and mortality rates. That is why DM management becomes a priority in preventing complications (State, 2013)

DM management includes regulating diet, physical activity, stress management, control of blood sugar levels and taking the medication regularly (Meng, Bai, Wang, Li, Wang, \& Chen, 2017). Long-term use of DM prescribes often causes side effects for DM patients such as indigestion (Didarloo et al., 2012). In addition, the use of long-term chemical drugs also burdens liver and kidney function (Almasdy et al., 2015). Low adherence in medication makes conventional therapy ineffective in lowering blood glucose levels (Boyoh, Kaawoan, \& Bidjuni, 2015). Therefore, people began to look for alternative herbs as the problemsolving. Noni (Morinda Citrifolia) is one of the medicinal plants that has been widely used in the community. However, the use of this herb is still limited to decreasing blood sugar level (Andréa et al., 2017).

Noni contains various active substances that are beneficial for health such as potassium, vitamin $\mathrm{C}$, flavanoid compounds, scopoletin, linoleic acid, molindone, alizarin and rubidium. Flavonoids are one of the hypoglycemic compounds (Aijratul et al., 2016). Many studies related to the use of noni on DM patients proved that noni can lower blood glucose levels (Fadillah, 2014). Those study population are DM patients who did not use medication. This study will seek the effect of noni in combination with oral antihyperglycemic drugs. Thus, joining noni with DM medicine affect lowering blood glucose levels to normal or causing hypoglycemia will be proven and leads to a better recommendation.

\section{Methods}

\section{Scope and Design}

The population of this study was DM patients who took DM drugs in the Siulak Mukai Public Health Center, Kerinci district. The sample used 16 DM patients divided into control groups and intervention groups. Each group consists of 8 people. This is a Quasy Experiment study with two group posttest design.

\section{Procedures}

Before the intervention, the blood glucose levels of all participants in both groups examined using glucose-check. The intervention group given the squeeze water of Noni fruit that made by blended the noni fruit with $100 \mathrm{ml}$ drink water then filtered to generate the extract. The intervention taken once a day carried out for ten days. The blood glucose levels were re-check after ten days for both groups.

\section{Data Collection and Data Analysis}

Data collected by taking one drop of patients' blood in the capillary blood vessels of index finger then checked with gluco-check to determine blood glucose levels. The data were analyzed statistically using the independent ttest.

\section{Results}

There is no attrition rate during this study; all respondents have participated until the end of the study. All patients continuously maintain heir diet following the recommendation of Siulak Mukai Public Health Center.

\section{Univariate Analysis}

The mean blood glucose level in the intervention and control group presented in Table 1.

Table 1. The mean blood glucose level in intervention and control group

\begin{tabular}{cccc}
\hline Variable & Mean & $\begin{array}{c}\text { Standard } \\
\text { Deviation (SD) }\end{array}$ & Min-Max \\
\hline $\begin{array}{c}\text { Intervention } \\
\text { group }\end{array}$ & 199,88 & 37,441 & $140-262$ \\
Control group & 326,25 & 94,841 & $198-460$ \\
\hline
\end{tabular}

Table 1 shows the average of blood glucose level in intervention group (post-test) is $199.88 \mathrm{mg} / \mathrm{dL}$, standard deviation $37.441 \mathrm{mg} / \mathrm{dL}$, minimum $140 \mathrm{mg} / \mathrm{dL}$ and maximum $262 \mathrm{mg} / \mathrm{dL}$ and $326.25 \mathrm{mg} / \mathrm{dL}$ in control group with standard deviation of $94.841 \mathrm{mg} / \mathrm{dL}$ and minimum $198 \mathrm{mg} / \mathrm{dL}$ and maximum $460 \mathrm{mg} / \mathrm{dL}$.

\section{Bivariate Analysis}

The effect of Noni juice on the decreased blood glucose level is presented in Table 2, describing the different level of blood glucose level in both groups is significant, with pvalue $0.003(\mathrm{p} \leq 0,005)$. 
Table 2. The effect of Noni (Morinda Citrifolia) Juice in blood glucose levels

\begin{tabular}{ccccc}
\hline $\begin{array}{c}\text { Blood } \\
\text { Biomarkers }\end{array}$ & Analysis & F & df & $\begin{array}{c}\text { Sig. } \\
(2 \text {-tailed })\end{array}$ \\
\hline $\begin{array}{c}\text { blood glucose } \\
\text { level }\end{array}$ & $\begin{array}{c}\text { Equal Variances } \\
\text { Assumed }\end{array}$ & 10,054 & 14 & 0,003 \\
\hline
\end{tabular}

\section{Discussions}

\section{Blood Glucose Levels in Intervention Group}

DM management, combined with utilizing natural ingredients is effective in lowering blood sugar levels. Morinda Citrifolia can lower blood sugar levels because it can increase insulin secretion (Lee et al., 2012). This is proven by the increase in insulin levels in blood plasma after consuming noni. In addition, noni is also rich in antioxidants that can reduce damage to pancreatic cells due to free radicals (Pattabiraman \& Muthukumaran, 2011)

Noni (Morinda Citrifolia) can also reduce lipid peroxidation, thus preventing organ complications due to hyperglycemia (Lee et al., 2012). In addition, it can also reduce blood lipid levels, thus reducing oxidation due to free radicals (Aijratul et al., 2016). The fibre content in Noni (Morinda Citrifolia) inhibit the absorption of blood sugar in the intestine and increase glucose storage in the liver (Andréa et al., 2017)

It can be assumed that the decreasing of blood sugar level in the intervention group is because Noni (Morinda Citrifolia) has several bioactive compounds such as flavonoids, triterpenes, triterpenoids and saponins in a high amount (Andréa et al., 2017). The compound is able to lower blood glucose levels by stimulating insulin secretion. It is also functioning as an antioxidant that reduces the effects of cyclicity due to hyperglycemia. Therefore, it can be excellently used for diabetes. Some of the participants $(50 \%)$ found to have only a slight decrease in blood glucose level where the blood sugar level of these respondents still above the normal limits. The reason for it is due to the obedience of diet and physical activity of respondents (Dafriani, 2017) where most of them still consume high fat and carbohydrates.

\section{Blood Glucose Levels in Control Group}

Blood glucose levels in the control group were higher than the intervention group but lower than blood glucose levels in the pretest measurement. Around $37.5 \%$ of respondents decreased blood glucose levels even though it is still above average. This decrease in blood glucose levels may be influenced by the use of oral antidiabetes drugs obtained from Public Health Center.

Some studies state that DM is also influenced by age and hereditary (genetic) factors (Brunner, Smeltzer, \& Suddarth, 2010), age influenced the resistance of the insulin resulted in increasing blood sugar levels. This study found that $62.5 \%$ of respondents had a family history of diabetes mellitus, $37.5 \%$ of respondents had no family history of diabetes mellitus, and all respondents are aged $\geq$ 40 years

DM is also influenced by unhealthy diets such as high intake of carbohydrates and fats. High-fat trigger the occurrence of insulin resistance. Fat is also one of the substances that are easily oxidized, thus increasing the risk of complications. Gender also affects the occurrence of DM (Aouacheri et al., 2015). Women tend to have lighter activities compared to men. In addition, women prefer to eat and consume snacks so that the intake of carbohydrates and fats is higher than men (Saraswati, 2016).

The declining of blood sugar levels in the control group happened because respondents in the control group took oral antihyperglycemic drugs. In addition, blood glucose levels can be controlled with diet and perform physical activities regularly (Rusandi et al., 2015). This study data shows $37.5 \%$ of respondents have a low-fat diet and limit the intake of sugar, rice and sweet foods. Also, there were $25 \%$ of respondents who did physical activities such as exercise and gardening.

\section{The Effect of Noni (Moringa citrifolia) on Blood Sugar Levels of DM Patients}

Noni juice is proven to lowering blood sugar level in DM patients ( $p$-value $=0.003(p \leq 0.05))$. Other studies also found that blood sugar level is declined in DM patients who took Noni capsules $(p=0.020(<0.05)$. The combination of pharmacology and herbs is effective in reducing hyperglycemia (Phakhodee, 2012). Decreased blood glucose levels in respondents who consumed noni with drugs are better than just taking drugs.

Fifty per cent of participants in this study have good compliance with the recommended diet. Administering noni juice therapy with adherence to the regular diet had better blood sugar levels compared to patients who had irregular diets. The DM diet consists of the choosing type of food, the amount of food and the schedule of meals. Dm patients should limit the number of carbohydrates and fats and avoid dinner. Restrictions on carbohydrates and fats can lower blood glucose levels (Idris \& Jafar, 2014). Patients who have habits of eating big meals after 5 PM in the afternoon tend to have higher blood glucose levels in the next morning compared to DM respondents who do not. The provision of this noni juice therapy can be chosen as one of the alternative treatments to lower blood sugar levels naturally, naturally safe and more affordable (Algenstaedt et al., 2018)

\section{Conclusions}

Noni (Morinda Citrifolia) is hypoglycemic, so it has the potential to help lowering blood glucose levels in DM 
patients. The use of noni can be a complementary therapy for DM patients.

\section{Declaration statement}

No potential conflict of interest was reported by the authors.

\section{Acknowledgements}

Acknowledgements are conveyed to all DM patients and the Chairman of Siulak Mukai Public Health Center, Kerinci.

\section{References}

Aijratul, N., Mohamad, A., Mustapha, N. M., \& Mohamed, S. (2016). Morinda citrifolia leaf enhanced performance by improving angiogenesis, mitochondrial biogenesis, antioxidant, anti-inflammatory \& stress responses. Food Chemistry, 212, 443-452. https://doi.org/10.1016/j.foodchem.2016.05.179

Algenstaedt, P., Stumpenhagen, A., \& Westendorf, J. (2018). The Effect of Morinda citrifolia L . Fruit Juice on the Blood Sugar Level and Other Serum Parameters in Patients with Diabetes Type 2. 2018.

Almasdy, D., Sari, D. P., Suhatri, S., Darwin, D., \& Kurniasih N. (2015). Evaluasi Penggunaan Obat Antidiabetik Pada Pasien Diabetes Melitus Tipe-2 di Suatu Rumah Sakit Pemerintah Kota Padang - Sumatera Barat. Jurnal Sains $\begin{array}{llll}\text { Farmasi \& } \quad \text { Klinis, } & 2(1),\end{array}$ https://doi.org/10.29208/jsfk.2015.2.1.58

Andi Mardhiyah Idris, Nurhaedar Jafar, R. I. (2014). Pola Makan Dengan Kadar Gula Darah Pasien DM Tipe 2. Jurnal MKMI, 211-218.

Andréa, M., Torres, O., Fátima, I. De, Magalhães, B., Mondêgo-oliveira, R., Sá, J. C. De, \& Rocha, A. L. (2017). One Plant, Many Uses: A Review of the Pharmacological Applications of Morinda citrifolia. 979(January), 971979. https://doi.org/10.1002/ptr.5817

Aouacheri, O., Saka, S., Krim, M., Messaadia, A., \& Maidi, I. (2015). The Investigation of the Oxidative StressRelated Parameters in Type2 Diabetes Mellitus. Canadian Journal of Diabetes, 39(1), 44-49. https://doi.org/10.1016/j.jcjd.2014.03.002

Babu, P. V. A., Liu, D., \& Gilbert, E. R. (2013). Recent advances in understanding the anti-diabetic actions of dietary flavonoids. In Journal of Nutritional Biochemistry (Vol. 24, Issue 11, pp. 1777-1789). https://doi.org/10.1016/j.jnutbio.2013.06.003

Brunner, L. S., Smeltzer, S. C. O., \& Suddarth, D. S. (2010). Brunner \& Suddarth's textbook of medical-surgical nursing. Lippincott Williams \& Wilkins.

Dafriani, P. (2017). Hubungan Pola Makan dan Aktifitas Fisik Terhadap Kejadian Diabetes Melitus di Poliklinik Penyakit Dalam RSUD dr . Rasidin Padang. 13(2).

Didarloo, A. R., Shojaeizadeh, D., Asl, R. G., Niknami, H. H. S., \& Pourali, R. (2012). Prediction of Self-Management Behavior among Iranian Women with Type 2 Diabetes:
Application of the Theory of Reasoned Action along with Self-Efficacy ( ETRA ). 14(2), 86-95.

DINKES Kabupaten Kerinci, (2019).

Fadillah, R. U. (2014). Antidiabetic Effect of Morinda Citrifolia L. As A Treatment of Diabetes Mellitus. J Majority, 3(7), 107-112. https://doi.org/10.1007/9783-662-03680-8_7

Forouhi, N. G., \& Wareham, N. J. (2014). Epidemiology of diabetes.

Lee, S., Park, S., Hwang, J., Yi, S., Nam, Y., \& Lim, S. (2012). Antidiabetic Effect of Morinda citrifolia ( Noni ) Fermented by Cheonggukjang in KK-A y Diabetic Mice. 2012. https://doi.org/10.1155/2012/163280

Leon, B. M. (2015). Diabetes and cardiovascular disease: Epidemiology, biological mechanisms, treatment recommendations and future research. World Journal of Diabetes, 6(13), 1246. https://doi.org/10.4239/wjd.v6.i13.1246

Meng, Y., Bai, H., Wang, S., Li, Z., Wang, Q., \& Chen, L. (2017). Efficacy of low carbohydrate diet for type 2 diabetes mellitus management: a systematic review and metaanalysis of randomized controlled trials. Diabetes Research and Clinical Practice, 131, 124-131.

Pattabiraman, K., \& Muthukumaran, P. (2011). Antidiabetic and Antioxidant Activity of Morinda tinctoria roxb Fruits Extract in Streptozotocin-Induced Diabetic Rats. 1(2), 34-39.

Phakhodee, W. (2012). Distribution of Naturally Occurring Anthraquinones, Iridoids and Flavonoids from Morinda Genus : Chemistry and Biological Activity. 9(3), 173-188.

Rusandi, D., Prabowo, T., Adinugraha, T. S., Jenderal, S., Yani, A., \& Yogyakarta, P. K. (2015). Pengaruh Senam Kaki Diabetes pada Penderita Diabetes Melitus. 4(1), 44-54.

Saraswati, A. T. (2016). Kejadian Sindrom Metabolik Pada Remaja Putri Stunted Obesity Di Pedesaan Jepara. Journal of Nutrition College, 5(3), 192-197. https://doi.org/10.14710/jnc.v5i3.16399

State, A., \& Biology, E. (2013). The pathogenesis and pathophysiology of type 1 and type 2 diabetes mellitus. 4(4), 46-57. https://doi.org/10.5897/JPAP2013.0001 